\title{
PENERAPAN MODEL CREATIVE PROBLEM SOLVING BERBANTUAN MEDIA BONGKAR PASANG UNTUK PENINGKATAN BERPIKIR KREATIF MATEMATIKA
}

\author{
Irma Yuliani $^{1 \bowtie}$, Mohammad Kanzunnudin ${ }^{2}$, dan Ratri Rahayu ${ }^{3}$ \\ Prodi Pendidikan Guru Sekolah Dasar, Universitas Muria Kudus \\ Prodi Pendidikan Bahasa dan Sastra Indonesia, Universitas Muria Kudus \\ Prodi Pendidikan Matematika, Universitas Muria Kudus
}

\begin{tabular}{l}
\hline Info Artikel \\
\hline Sejarah Artikel: \\
Diterima 25 Feb 2018 \\
Direvisi 20 Mar 2018 \\
Disetujui 20 Apr 2018 \\
\hline \\
Keywords: Creative \\
Problem Solving, \\
Creative Thinking \\
Ability, Cube Nets and \\
Cuboids. \\
\end{tabular}

Paper type:

Research paper

\begin{abstract}
This research aims are to know the improvement of the Mathematics creative thinking ability of the fourth grade students at SD 1 Wergu Kulon by using Creative Problem Solving model assisted by puzzle media. The research was conducted to the fourth grade at SD 1 Wergu Kulon year 2016/2017 with 23 students as respondents. The method of the research was a classroom action research that was done in 2 cycles; cycle I and cycle II. Every cycle consists of action, observation, and reflection. The independent variable of this research was Creative Problem Solving model, while the dependent variable was the Mathematics creative thinking ability. Technique of collecting data of the research was interview, observation, test and documentation. The data analysis of the research was quantitative and qualitative analysis. The finding of the research showed the average score of the teacher's teaching ability in cycle I was 3,14 (good), then cycle II had an improvement became 3,40 (very good). The average score of the students' activity showed that there was an improvement of the students' activity from cycle I 2,315 (enough) became 2,82 (good) in cycle II. It also showed that there was an improvement of the Mathematics creative thinking of cube nets and cuboids material from cycle I was 56,52\% (medium), then cycle II was 78,26\% (high).
\end{abstract}

\begin{abstract}
Abstrak
Penelitian ini bertujuan untuk mengetahui peningkatan kemampuan berpikir kreatif matematika dengan diterapkannya model Creative Problem Solving berbantuan media bongkar pasang. Penelitian dilaksanakan di kelas IV SD 1 Wergu Kulon tahun pelajaran 2016/2017 dengan jumlah siswa 23. Metode yang digunakan yakni metode penelitian tindakan kelas yang berlangsung selama 2 siklus yaitu siklus I dan siklus II. Masing-masing siklus terdiri atas perencanaan, pelaksanaan, pengamatan, dan refleksi. Variabel bebas pada penelitian ini yakni model Creative Problem Solving, sedangkan variabel terikatnya yakni kemampuan berpikir kreatif matematika. Teknik pengumpulan data yang digunakan yaitu teknik wawancara, observasi, tes, dan dokumentasi. Analisis data yang digunakan yaitu analisis data kuantitatif dan analisis data kualitatif.Hasil penelitian menunjukkan bahwa skor rata-rata keterampilan mengajar guru pada siklus I mencapai 3,14 (baik), pada siklus II mengalami peningkatan menjadi 3,40 (sangat baik). Skor rata-rata aktivitas belajar siswa juga mengalami peningkatan dari siklus I memperoleh 2,31 (cukup), dan pada siklus II memperoleh 2,82 (baik). Hasil penelitian juga menunjukkan adanya peningkatan berpikir kreatif matematika pada materi jaring-jaring kubus dan balok dari siklus I mencapai ketuntasan 56,52\% (sedang) ke siklus II mencapai ketuntasan 78,26\% (tinggi).
\end{abstract}

(C) 2018 Universitas Muria Kudus

\footnotetext{
Alamat korespondensi:

Program Studi Pendidikan Matematika

Fakultas Keguruan dan Ilmu Pendidikan Universitas Muria Kudus

Kampus UMK Gondangmanis, Bae Kudus Gd. L. It I PO. BOX 53 Kudus

Tlp (0291) 438229 ex.147 Fax. (0291) 437198

E-mail: yuliani.irma07@gmail.com
} 


\section{PENDAHULUAN}

Masih banyak siswa yang menganggap bahwa pelajaran matematika merupakan pelajaran yang sulit dan membingungkan. Hal tersebut merupakan salah satu masalah yang sering ditemukan dalam sekolah khususnya pada sekolah dasar. Selain itu, kemampuan berpikir kreatif siswa yang rendah juga menyebabkan rendahnya hasil belajar dan kemampuan siswa dalam pelajaran matematika.

Matematika merupakan salah satu bidang studi yang ada pada semua jenjang pendidikan, mulai dari tingkat sekolah dasar hingga perguruan tinggi (Susanto, 2016:183) Matematika merupakan salah satu mata pelajaran di sekolah dasar yang sangat penting dan harus dikuasai oleh siswa. Khususnya pada tingkat sekolah dasar, pembelajaran matematika mempunyai tujuan, salah satu tujuannya ditunjukkan oleh Suherman, dkk (dalam Sudewa, dkk, 2014) bahwa tujuan pembelajaran matematika di sekolah dasar adalah untuk mempersiapkan siswa agar sanggup menghadapi perubahan keadaan di dunia yang selalu berkembang dan mempersiapkan siswa agar dapat menggunakan matematika dan pola pikir matematika dalam kehidupan sehari-hari. Matematika perlu diberikan kepada siswa untuk membekali mereka dengan kemampuan berpikir logis, analitis, sistematis, kritis, dan kreatif serta kemampuan bekerjasama (Syafri, 2016:10).

Berpikir kreatif sangatlah penting dalam pembelajaran di sekolah, terutama pada matematika di sekolah dasar, karena sekolah dasar merupakan pondasi awal pembangunan konsep matematika yang akan membekas di pikiran seorang siswa sekolah dasar hingga ia dewasa nanti. Purwanti (2015:65-66) menjelaskan bahwa seseorang dikatakan mempunyai kreativitas jika mencapai 4 indikator kreativitas yakni kelancaran, keluwesan, keaslian, keterperincian.

Bishop (dalam Suriyani, 2015:227) mengemukakan bahwa berpikir kreatif dalam pembelajaran matematika memang sangat penting, karena seseorang memerlukan dua keterampilan berpikir matematis, yaitu berpikir kreatif yang sering diidentikkan dengan intuisi dan kemampuan berpikir analitik yang diidentikkan dengan kemampuan berpikir logis.

Rosdiana, dkk (2016) menyatakan bahwa kemampuan berpikir kreatif matematika siswa pada jenjang sekolah dasar bisa dikatakan masih rendah. Rendahnya kemampuan tersebut ditunjukkan oleh hasil TIMMS (Trends in International Mathematics and Science Study). TIMMS merupakan studi yang mengukur kemampuan berpikir tingkat tinggi, karena soal yang ada pada TIMMS bersifat kontekstual yang di dalamnya menuntut siswa untuk berpikir kreatif. Indonesia dalam ajang TIMMS tahun 2015 menduduki peringkat ke-44 dari 56 negara dengan perolehan skor 397 (IEA, 2015). Hal tersebut menunjukkan bahwa kemampuan berpikir kreatif matematika yang dimiliki oleh siswa negara Indonesia masih di bawah rata-rata dari beberapa negara di dunia.

Rendahnya kemampuan berpikir kreatif siswa pada mata pelajaran matematika juga dialami oleh salah satu sekolah dasar yang terletak di Kabupaten Kudus yakni di SD 1 Wergu Kulon khususnya pada kelas IV tahun pelajaran 2016/2017. Hal tersebut terbukti dari hasil tes kemampuan berpikir kreatif matematika siswa pada prasiklus yang sudah dilakukan. Nilai rata-rata kelas yang diperoleh yaitu 53,91 dan nilai terendah yang diperoleh siswa yaitu 27 . Siswa yang nilai tes berpikir kreatif matematikanya melebihi batas kriteria ketuntasan minimal yakni ada 7 siswa $(39,43 \%)$, sedangkan 16 siswa lainnya masih berada di bawah kriteria ketuntasan minimal $(60,57 \%)$.

Rendahnya kemampuan berpikir kreatif matematika siswa disebabkan oleh beberapa faktor, diantaranya kurangnya keaktifan dan partisipasi siswa pada proses kegiatan pembelajaran. Banyak siswa yang kurang memperhatikan penjelasan guru saat menerangkan pelajaran, siswa berbicara sendiri dengan teman-temannya. Hal tersebut tentunya berakibat pada rendahnya kemampuan berpikir kreatif matematika siswa dan peran aktif siswa dalam kegiatan pembelajaran.

Selain itu, berdasarkan hasil wawancara yang telah dilakukan pada siswa kelas IV SD 1 Wergu Kulon, menunjukkan informasi bahwa mata pelajaran matematika merupakan mata pelajaran yang masih dianggap sulit, membingungkan, dan rata-rata siswa tidak suka mata pelajaran matematika. Diperoleh pula informasi bahwa kegiatan pembelajaran masih bersifat konvensional dan siswa kurang aktif maupun berpartisipasi dalam kegiatan pembelajaran.

Pembelajaran yang bersifat konvensional dan kurang melibatkan siswa dalam pembelajaran dapat menghambat aktivitas dan pola berpikir kreatif pada siswa. Sehingga mempengaruhi kemampuan berpikir yang kreatif dan hasil belajar siswa khususnya dalam mata pelajaran matematika. Amalia, dkk (2015) menyatakan selayaknya guru harus mengembangkan kemampuan berpikir tingkat tinggi siswa yaitu kemampuan berpikir kreatif dalam pembelajaran matematika di kelas. 
Penggunaan model dalam kegiatan pembelajaran akan menciptakan suasana yang menyenangkan, membuat siswa merasa senang, hasil belajar siswa dapat tercapai secara optimal, serta dapat menumbuhkembangkan berpikir kreatif siswa. Ada berbagai macam model pembelajaran, salah satunya yakni model pembelajaran Creative Problem Solving (CPS). Model Creative Problem Solving (CPS) adalah model pembelajaran yang sistematis dalam menyelesaikan masalah dengan cara atau strategi yang kreatif. Lestari dan Yudhanegara (2015:65), bahwa model Creative Problem Solving merupakan variasi dari pembelajaran penyelesaian masalah dengan teknik yang sistematis dalam mengorganisasikan gagasan kreatif untuk menyelesaikan suatu permasalahan. Creative Problem Solving merupakan salah satu model pembelajaran yang digunakan dalam upaya menciptakan solusi permasalahan dengan cara yang kreatif dan imajinatif sehingga mendorong siswa untuk lebih terampil dan kreatif. Tahapan model pembelajaran Creative Problem Solving menurut Lestari dan Yudhanegara (2015:65-66) sebagai berikut.

1. Siswa dibentuk menjadi beberapa kelompok yang heterogen.

2. Pembelajaran dimulai dengan pemberian masalah sesuai dengan materi pelajaran melalui tanya jawab lisan.

3. Siswa dalam kelompok menentukan permasalahan yang tersedia dalam lembar kerja kelompok.

4. Siswa dalam kelompok menentukan gagasan/ide sehingga dapat dijadikan solusi.

5. Siswa melakukan presentasi yang diwakili seorang siswa dari satu kelompok.

6. Diskusi kelompok untuk menyimpulkan materi yang telah disampaikan.

Menciptakan pembelajaran yang menyenangkan tidak hanya menerapkan model pembelajaran dalam proses belajar mengajar, melainkan juga didukung dengan adanya media pembelajaran. Media yang diterapkan dalam penelitian ini yakni media bongkar pasang untuk mempermudah siswa dalam menemukan jaringjaring kubus maupun balok. Media bongkar pasang merupakan alat permainan edukatif yang dapat merangsang berbagai kemampuan anak, media bongkar pasang dimainkan dengan cara membongkar kepingan bongkar pasang lalu memasangnya kembali ataupun sebaliknya, baik bongkar pasang dua dimensi atau tiga dimensi (Hasnawati, 2016). Media bongkar pasang yang digunakan pada penelitian ini yakni media yang terdiri atas potongan-potongan berbentuk bangun datar persegi maupun persegi panjang yang kemudian dapat digabung-gabungkan menjadi bangun kubus maupun balok. Media bongkar pasang dimodifikasi dengan memberikan angka pada setiap sisinya guna mempermudah siswa untuk menentukan alas dan tutup bangun ruang kubus dan bangun ruang balok.

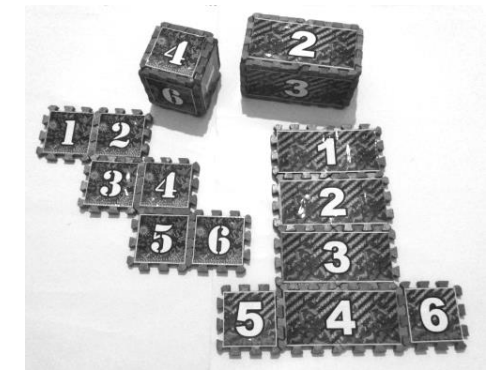

Gambar 1 Media Bongkar Pasang

Media bongkar pasang ini dapat melibatkan siswa secara langsung dalam pembelajaran sehingga dengan cara yang kreatif dapat menemukan sendiri berbagai macam jaring-jaring kubus dan balok. Menerapkan model Creative Problem Solving dengan berbantuan media bongkar pasang diharapkan menarik perhatian siswa dan dapat memfokuskan tujuan pembelajaran sehingga dapat menumbuhkembangkan kemampuan berpikir kreatif matematika siswa khususnya pada materi jaring-jaring kubus dan balok.

Berdasarkan uraian tersebut, maka peneliti melakukan tindakan dengan menerapkan model Creative Problem Solving berbantuan media bongkar pasang pada mata pelajaran matematika materi jaring-jaring kubus dan balok untuk meningkatkan kemampuan berpikir kreatif matematika siswa kelas IV di SD 1 Wergu Kulon.

\section{METODE PENELITIAN}

Penelitian ini merupakan penelitian tindakan kelas yang mengacu pada model yang dikemukakan oleh Kemmis dan Mc. Taggart. Penelitian dilakukan dalam dua siklus yakni siklus I dan siklus II. pada setiap siklus meliputi 4 tahapan yaitu perencanaan, pelaksanaan, pengamatan, dan refleksi. Sebagaimana dijelaskan Arikunto (2014:16) bahwa secara garis besar terdapat empat tahapan pada penelitian tindakan kelas yakni (1) perencanaan, (2) pelaksanaan, (3) pengamatan, (4) refleksi. Adapun variabel bebas pada penelitian ini yakni model Creative Problem Solving. Sedangkan variabel terikat pada penelitian ini yakni kemampuan berpikir kreatif matematika siswa.

Teknik pengumpulan data yang digunakan dalam penelitian yakni metode wawancara, observasi, tes, dan dokumentasi. Adapun instrumen yang digunakan yaitu lembar 
wawancara, lembar observasi, lembar tes, dan dokumentasi. Untuk menganalisis data yang diperoleh, maka digunakan teknik analisis data kuantitatif dan analisis data kualitatif. Analisis data kuantitatif digunakan untuk mengetahui peningkatan kemampuan berpikir kreatif matematika siswa kelas IV SD 1 Wergu Kulon pada materi jaring-jaring kubus dan balok dengan diterapkannya model Creative Problem Solving berbantuan media bongkar pasang. Menghitung nilai tiap indikator kemampuan berpikir kreatif matematika dengan rumus sebagai berikut.

$\frac{\text { jumlah skor tiapindikator }}{\text { jumlah skor maksimal tiapindikator }} \times 100$

Sumber: Sugiyono (2015:418)

Adapun kriteria kemampuan berpikir kreatif tiap indikator disajikan pada Tabel 1.

Tabel 1. Kriteria Kemampuan Berpikir Kreatif Tiap Indikator

\begin{tabular}{cc}
\hline $\begin{array}{c}\text { Nilai Kemampuan Berpikir } \\
\text { Kreatif Tiap Indikator }\end{array}$ & Kriteria \\
\hline $0 \leq$ nilai $\leq 20$ & Sangat kurang \\
\hline $20<$ nilai $\leq 40$ & Kurang \\
\hline $40<$ nilai $\leq 60$ & Cukup \\
\hline $60<$ nilai $\leq 80$ & Baik \\
\hline $80<$ nilai $\leq 100$ & Sangat baik
\end{tabular}

Menghitung nilai kemampuan berpikir kreatif matematika siswa secara individu (ketuntasan belajar individu), dengan rumus sebagai berikut.

$$
=\frac{\text { skor yang dipenoleh }}{\text { skor maksimum }} x 100
$$

Sumber: Arifin (2013:128)

Adapun kriteria ketuntasan belajar disajikan pada Tabel 2.

Tabel 2. Kriteria Ketuntasan Belajar

\begin{tabular}{cc}
\hline Nilai & Kriteria \\
\hline$\geq 65$ & Tuntas \\
\hline$<65$ & Tidak Tuntas \\
\hline \multicolumn{3}{c}{ KKM 65 } \\
\hline Menghitung persentase & kemampuan
\end{tabular}

berpikir kreatif matematika siswa secara klasikal, dengan rumus.

$$
\frac{j u m l a h \text { siswa yang tuntas belajar }}{\text { jumlah siswa }} \times 100 \%
$$

Sumber: Aqib (2014:41)

Perhitungan persentase kemampuan berpikir kreatif siswa yang sudah diperoleh dapat dikategorikan ke dalam kriteria kemampuan berpikir kreatif matematika. Adapun kriteria tersebut disajikan pada Tabel 3.
Tabel 3. Kriteria Kemampuan Berpikir Kreatif Matematika

\begin{tabular}{lc}
\hline Persentase Kemampuan & Kriteria \\
Berpikir Kreatif Matematika & Sangat tinggi \\
$80 \%-100 \%$ & Tinggi \\
$60 \%-79 \%$ & Sedang \\
$40 \%-59 \%$ & Rendah \\
$20 \%-39 \%$ & Sangat rendah \\
$0 \%-19 \%$ & Sumber: Aqib (2014:41) \\
Sedangkan analisis data kualitatif \\
diperoleh melalui lembar observasi yakni \\
observasi keterampilan mengajar guru dan \\
aktivitas belajar siswa pada pembelajaran \\
matematika dengan menerapkan model Creative \\
Problem Solving berbantuan media bongkar \\
pasang. Data yang sudah diperoleh dari hasil \\
observasi keterampilan mengajar guru dan \\
aktivitas belajar siswa kemudian dilakukan \\
penilaian dengan cara menghitung skor rata-rata \\
yang diperoleh, yaitu menggunakan rumus \\
sebagai berikut.
\end{tabular}

Skor rata-rata $=\frac{\text { total skor yang diperoleh }}{\text { jumlah indikator penilaian }}$ mengkategorikan aktivitas belajar siswa dan keterampilan mengajar guru berdasarkan skor rata-rata yang diperoleh, yakni ada pada Tabel 4.

Tabel 4. Kriteria Keterampilan Mengajar Guru dan Aktivitas Belajar Siswa

\begin{tabular}{cc}
\hline Persentase & Kriteria \\
\hline $3,25<$ skor rata-rata $\leq 4$ & Sangat baik \\
$2,5<$ skor rata-rata $\leq 3,25$ & Baik \\
$1,75<$ skor rata-rata $\leq 2,5$ & Cukup \\
$1<$ skor rata-rata $\leq 1,75$ & Kurang \\
\hline \multicolumn{2}{c}{ Sumber: Kosasih $(2014: 135)$}
\end{tabular}

Indikator keberhasilan pada penelitian ini sebagai berikut.

1. Keterampilan mengajar guru pada pelaksanaan pembelajaran matematika dengan model Creative Problem Solving berbantun media bongkar pasang pada materi jaring-jaring kubus dan balok minimal mencapai skor rata-rata $\geq 2,5$ dengan kriteria baik.

2. Skor rata-rata aktivitas belajar yang diperoleh siswa kelas IV SD 1 Wergu Kulon minimal mencapai skor rata-rata $\geq$ 2,5 dengan kriteria baik.

3. Ketercapaian kemampuan berpikir kreatif matematika secara klasikal yang diperoleh siswa kelas IV SD 1 Wergu Kulon mencapai persentase $\geq 60 \%$ pada kriteria tinggi. 


\section{HASIL DAN PEMBAHASAN}

Penelitian tindakan kelas berlangsung selama 2 siklus yakni siklus I dan siklus II. Pada setiap siklusnya terdiri atas 2 pertemuan. Pada siklus I pertemuan I dilaksanakan pada $22 \mathrm{Mei}$ 2017 dan pada siklus I pertemuan II dilaksanakan pada 23 Mei 2017. Sedangkan pada siklus II pertemuan I dilaksanakan pada $29 \mathrm{Mei}$ 2017 dan pada siklus II pertemuan II dilaksanakan pada 30 Mei 2017.

Pada setiap akhir siklus dilaksanakan evaluasi untuk mengetahui peningkatan kemampuan berpikir kreatif matematika yang dimiliki siswa kelas IV SD 1 Wergu Kulon. Berdasarkan hasil tes yang dilakukan pada akhir siklus I, diperoleh bahwa hasil nilai rata-rata kelas yaitu 74,35 dengan nilai terendah yang didapat siswa yaitu 30,83 .

Hasil tes evaluasi siklus I siswa kelas IV SD 1 Wergu Kulon tahun pelajaran 2016/2017 secara klasikal menunjukkan bahwa dari jumlah siswa keseluruhan yakni 23 siswa terdapat 13 yang memperoleh ketuntasan melebihi nilai KKM dan terdapat 10 siswa yang tidak tuntas melebihi nilai KKM. Jika disajikan dalam persentase, maka siswa yang memperoleh ketuntasan yakni $56,52 \%$, sedangkan siswa yang tidak tuntas yakni $43,48 \%$. Jika dianalisis pada kriteria ketuntasan secara klasikal, maka kemampuan berpikir kreatif matematika siswa kelas IV SD 1 Wergu Kulon pada evaluasi siklus I termasuk kedalam kriteria sedang. Hal tersebut perlu adanya tindakan kembali untuk meningkatkan kemampuan berpikir kreatif matematika yang dimiliki oleh siswa. Persentase hasil ketuntasan siswa secara klasikal dapat disajikan dalam bentuk diagram pada gambar 2 .

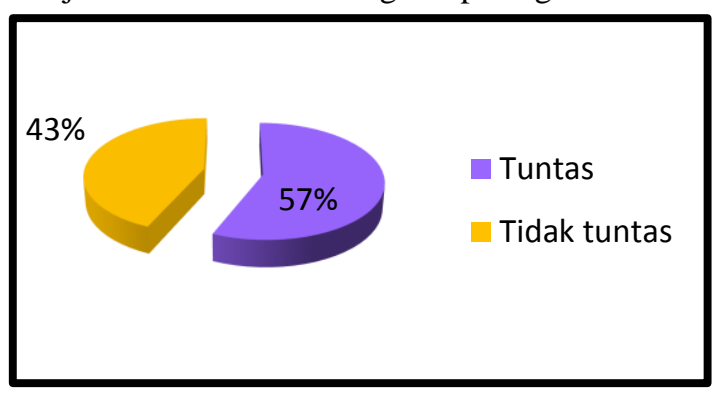

Gambar 2 Hasil Tes Evaluasi Siklus I

Penelitian tindakan kelas dengan menerapkan model Creative Problem Solving berbantuan media bongkar pasang pada siswa kelas IV SD 1 Wergu Kulon tahun pelajaran 2016/2017 pada siklus I, belum dapat dikatakan berhasil karena kemampuan berpikir kreatif matematika yang dimiliki siswa belum mencapai indikator keberhasilan yang diinginkan oleh peneliti yakni mencapai persentase $\geq 60 \%$ dengan kriteria tinggi. Oleh karena itu, untuk memperbaiki hasil tes evaluasi pada siklus II, peneliti perlu memberikan himbauan kepada siswa untuk lebih memperhatikan saat mengikuti pelajaran dan lebih berkonsentrasi serta bersungguh-sungguh dalam mengerjakan tes evaluasi agar tidak lagi mengalami kesulitan dan mendapatkan nilai yang maksimal.

Berdasarkan tes soal kemampuan berpikir kreatif matematika pada siklus II pada siswa kelas IV SD 1 Wergu Kulon tahun pelajaran 2016/2017, diperoleh hasil nilai ratarata kelas yaitu 76,96 dengan nilai terendah yang didapat siswa yaitu 55,83. Hasil tes evaluasi siklus II, secara klasikal menunjukkan bahwa dari jumlah siswa keseluruhan yakni 23 siswa terdapat 18 siswa yang memperoleh ketuntasan melebihi nilai KKM dan terdapat 5 siswa yang tidak tuntas melebihi nilai KKM. Jika disajikan dalam persentase, maka siswa yang memperoleh ketuntasan yakni $78,26 \%$, sedangkan siswa yang tidak tuntas yakni $21,74 \%$. Jika dianalisis pada kriteria ketuntasan secara klasikal, maka kemampuan berpikir kreatif matematika siswa kelas IV SD 1 Wergu Kulon pada evaluasi siklus II termasuk kedalam kriteria tinggi. Hasil tersebut menunjukkan adanya peningkatkan kemampuan berpikir kreatif matematika yang dimiliki oleh siswa dari hasi tes evaluasi yang dilakukan pada siklus I yakni dengan memperoleh ketuntasan 56,52\%. Persentase hasil ketuntasan siswa secara klasikal dapat disajikan dalam bentuk diagram pada gambar 3 .

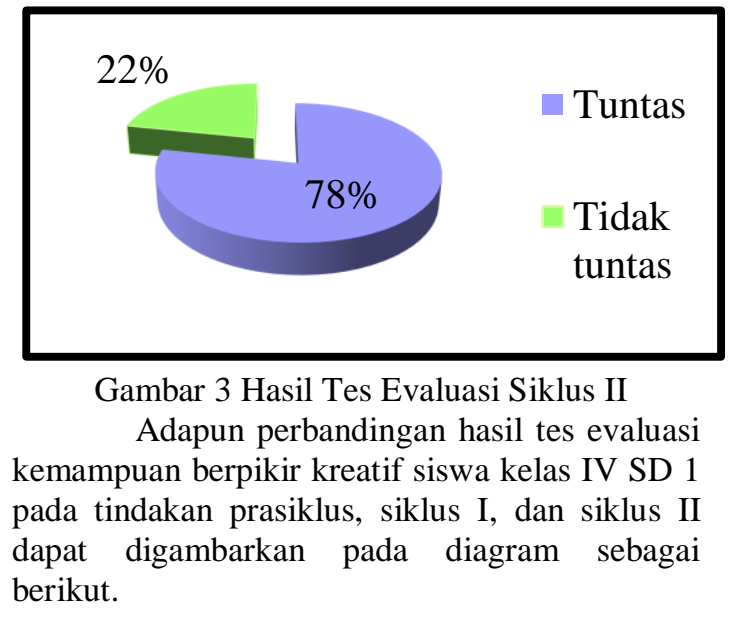




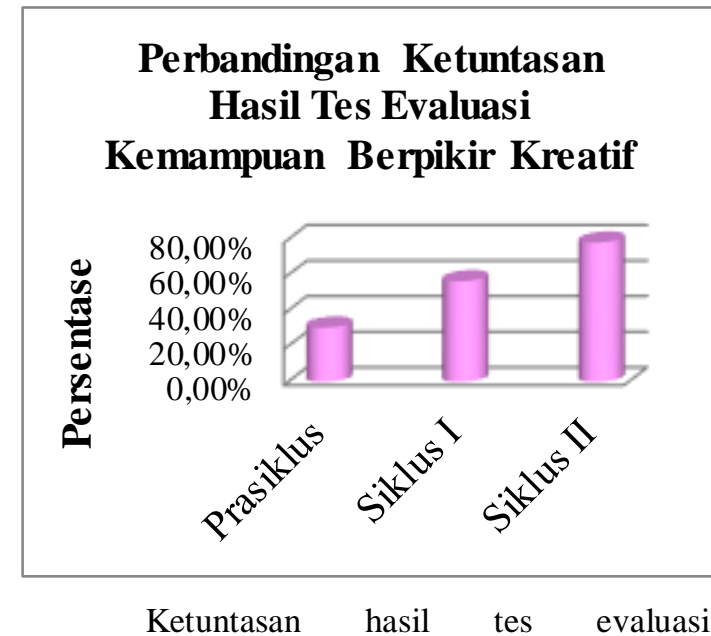
kemampuan berpikir kreatif kelas IV SD 1 Wergu Kulon mengalami peningkatan dari setiap tindakan. Ketuntasan hasil tes prasiklus sebesar $30,43 \%$ (rendah), ketuntasan hasil tes siklus I sebesar 56,52\% (sedang), dan ketuntasan hasil tes siklus II sebesar 78,26\% (tinggi). Demikian penelitian tindakan kelas dengan menerapkan model Creative Problem Solving berbantuan media bongkar pasang pada siswa kelas IV SD 1 Wergu Kulon tahun pelajaran 2016/2017 sudahdapat dikatakan berhasil karena kemampuan berpikir kreatif matematika yang dimiliki siswa sudah mencapai indikator keberhasilan yang diinginkan oleh peneliti yakni mencapai persentase $\geq 60 \%$ dengan kriteria tinggi.

Meningkatnya kemampuan berpikir kreatif matematika siswa disebabkan oleh adanya penerapan model Creative Problem Solving berbantuan media bongkar pasang pada pembelajaran. Model Creative Problem Solving merupakan model pembelajaran yang mengupayakan memecahkan suatu permasalahan dengan cara yang kreatif sehingga dapat menghasilkan suatu kreativitas. Sesuai dengan pendapat Sumartono dan Yustari (2014:191) bahwa model pembelajaran Creative Problem Solving menuntut siswa untuk mengerahkan semua cara dalam berpikir yang bertujuan untuk menyelesaikan suatu permasalahan secara kreatif sehingga pada pembelajaran siswa diberikan kebebasan untuk mengembangkan kemampuannya dalam berpikir secara kreatif dan mengasah kreativitas untuk menyelesaikan permasalahan. Proses yang seperti inilah harus dilakukan oleh siswa secara berulang dapat mengakibatkan kemampuan berpikir kreatif siswa dapat berkembang secara optimal.

Hasil observasi keterampilan mengajar guru dari siklus I ke siklus II pada pembelajaran matematika dengan menerapkan model Creative Problem Solving berbantuan media bongkar pasang pada siswa kelas IV SD 1 Wergu Kulon menunjukkan adanya peningkata. Peningkatan hasil observasi keterampilan mengajar guru dapat dilihat pada perbandingan hasil observasi pada siklus I dan siklus II. Hasil observasi keterampilan mengajar guru siklus I pertemuan I diperoleh total 76 dan skor rata-rata 3,04 dengan kriteria baik. Sedangkan pada siklus I pertemuan II diperoleh total skor 81 dan skor rata-rata 3,24 dengan kriteria baik. Hasil observasi keterampilan mengajar guru pada siklus II pertemuan I diperoleh total skor 84 dan skor ratarata 3,36 dengan kriteria sangat baik. Pada siklus II pertemuan II diperoleh total skor 86 dan skor rata-rata 3,44 dengan kriteria sangat baik. Hasil rata-rata observasi pada siklus I sebesar 3,14 dengan kriteria baik dan pada siklus II diperoleh rata-rata sebesar 3,40 dengan kriteria sangat baik.

Hasil observasi aktivitas belajar siswa juga menunjukkan adanya peningkatan. Pada siklus I pertemuan I memperoleh total skor 931 dan skor rata-rata 2,25 dengan kriteria cukup, serta pada pertemuan II memperoleh total skor 984 dan skor rata-rata 2,38 dengan kriteria cukup. Sedangkan pada siklus II pertemuan I memperoleh total skor 1126 dan skor rata-rata 2,72 dengan kriteria baik. Pada siklus II pertemuan II memperoleh total skor 1207 dan skor rata-rata 2,92 dengan kriteria baik. Berdasarkan hasil pada siklus I dan siklus I, maka diperoleh hasil rata-rata pada siklus I sebesar 2,315 dengan kriteria cukup dan rata-rata pada siklus II sebesar 2,82 dengan kriteria baik.

Penelitian tindakan kelas ini dapat dikatakan berhasil dengan tercapainya semua indikator keberhasilan yang diinginkan oleh peneliti. Keterampilan mengajar guru memperoleh rata-rata sebesar 3,40 dengan kriteria sangat baik. Aktivitas belajar siswa memperoleh rata-rata sebesar 2,82 dengan kriteria baik. Selanjutnya ketercapaian kemampuan berpikir kreatif matematika secara klasikal mencapai $78,26 \%$ pada kriteria tinggi. Oleh karena itu, maka dapat disimpulkan bahwa pembelajaran matematika pada materi jairngjaring kubus dan jaring-jaring balok dengan menggunakan model Creative Problem Solving berbantuan media bongkar pasang dapat meningkatkan kemampuan berpikir kreatif matematika pada siswa sekolah dasar khususnya siswa kelas IV SD 1 Wergu Kulon tahun pelajaran 2016/2017.

\section{SIMPULAN}

Berdasarkan pada hasil penelitian tindakan kelas yang sudah dilakukan pada siswa kelas IV di SD 1 Wergu Kulon serta berdasarkan pembahasan yang telah dibahas pada bab 
sebelumnya, maka dapat diketahui bahwa dalam pembelajaran matematika dengan menerapkan model Creative Problem Solving berbantuan media bongkar pasang dapat meningkatkan kemampuan berpikir kreatif matematika siswa sekolah dasar. Adapun simpulan hasil penelitian tindakan kelas sebagai berikut: (1) Skor rata-rata keterampilan mengajar guru dalam pengelolaan pembelajaran dengan menggunakan model Creative Problem Solving berbantuan media bongkar pasang pada siklus I memperoleh skor rata-rata 3,14 dengan kriteria baik. Pada siklus II skor rata-rata mengalami peningkatan yakni memperoleh skor rata-rata sebesar 3,40 dengan kriteria sangat baik; (2) Skor rata-rata aktivitas belajar siswa dalam kegiatan pembelajaran pada siklus I memperoleh skor rata-rata 2,31 dengan kriteria cukup dan pada siklus II mengalami peningkatan yakni memperoleh skor rata-rata 2,82 dengan kriteria baik; (3) Hasil kemampuan berpikir kreatif matematika dengan menerapkan model Creative Problem Solving berbantuan media bongkar pasang memperoleh hasil yang baik dengan meningkatnya hasil pada siklus I ke siklus II. Pada siklus I diperoleh ketuntasan klasikal sebesar 56,52\% dengan kriteria sedang. Pada siklus II diperoleh ketuntasan klasikal sebesar 78,26\% dengan kriteria tinggi. Perolehan rata-rata kelas pun juga meningkat yakni pada siklus I sebesar 60,11 dan pada siklus II sebesar 68,19 .

\section{UCAPAN TERIMA KASIH}

Ucapan terima kasih kepada (1) Dr. Slamet Utomo, M.Pd. selaku dekan FKIP UMK; (2) Ika Oktavianti, M.Pd., ketua Prodi PGSD UMK.; (3) Kepala SD 1 Wergu Kulon; (4) guru kelas IV SD 1 Wergu Kulon; (5) seluruh siswa kelas IV SD 1 Wergu Kulon; (6) seluruh pihak yang telah membantu dalam penelitian ini.

\section{DAFTAR PUSTAKA}

Terima kasih kepada semua pihak yang telah membantu dalam keberlangsungan penelitian ini.

Amalia, Yuli, dkk. 2015. Penerapan Model Eliciting Activities untuk Meningkatkan Kemampuan Berpikir Kreatif Matematis dan Self Confidence Siswa SMA. Journal Didaktik Matematika, 2(2): Hlm. 38-48.

Aqib, Zainal, dkk. 2014. Penelitian Tindakan Kelas (PTK) untuk guru SD, SLB, TK. Bandung: Yrama Widya.

Arifin, Zainal. 2013. Evaluasi Pembelajaran: Prinsip, Teknik, Prosedur. Bandung: PT Remaja Rosdakarya.

Arikunto, Suharsimi. 2014. Penelitian Tindakan Kelas. Jakarta: PT Bumi Aksara.
Hasnawati, dkk. 2016. Implementasi Permainan Bongkar Pasang Dalam Melejitkan Berbagai Aspek Perkembangan Anak Usia Dini Pada Paud It Ar-Rahman Banda Aceh. Jurnal Ilmiah Mahasiswa Pendidikan Anak Usia Dini, 1(1): 19-28.

IEA. 2015. TIMSS 2015 International Results in Mathematics, [online], (http://timss2015. org/download-center, diakses tanggal 28 Maret 2018).

Kosasih, E. 2014. Strategi Belajar dan Pembelajaran Implementasi Kurikulum 2013. Bandung: Yrama Widya.

Lestari, Karunia Eka dan Mokhammad Ridwan Yudhanegara. 2015. Penelitian Pendidikan Matematika. Bandung: Refika Aditama.

Purwanti, Duwi. 2015. Peningkatan Kreativitas dan Prestasi Belajar Matematika Siswa Kelas III SDN Gejayan Dengan Menggunakan Pendekatan PMRI. Jurnal INDI-Inovasi Didaktik, 1(1): 65-78.

Rosdiana, Daniar dkk. 2016. Pendekatan Eksploratif Untuk Meningkatkan Kemampuan Berpikir Kreatif dan Disposisi Matematika. Jurnal Pena Ilmiah, 1(1): 231-240.

Sudewa, Dewa Gede Oka, dkk. 2014. Implementasi Model Pembelajaran Creative Problem Solving Dengan Media Flash CD Untuk Meningkatkan Motivasi dan Hasil Belajar Matematika Pada Siswa Kelas V Semester I SD Negeri 6 Sukowati. E-Jurnal Mimbar PGSD Universitas Pendidikan Ganesha, 2(1).

Sugiyono. 2015. Metode Penelitian Pendidikan: Pendekatan Kuantitatif, Kualitatif, dan $R \& D$. Bandung: Alfabeta.

Sumartono dan Erik Yustari. 2014. Penerapan Model Creative Problem Solving (CPS) Dalam Pembelajaran Matematika di Kelas VIII SMP. EDU-MAT Jurnal Pendidikan Matematika, 2(3): 187-193.

Suriyani, dkk. 2015. Peningkatan Kemampuan Berpikir Kreatif dan Kemandirian Belajar Siswa Mts Negeri 2 Medan Melalui Pembelajaran Matematika Dengan Pendekatan Open-Ended. Jurnal Tabularasa PPS UNIMED, 12(3): 224234.

Susanto, Ahmad. 2016. Teori Belajar \& Pembelajaran di Sekolah Dasar. Jakarta: Prenadamedia Group.

Syafri, Fatrima Santri. 2016. Pembelajaran Matematika Pendidikan Guru SD/MI. Yogyakarta: Matematika. 
Irma Yuliani, Mohammad Kanzunnudin, dan Ratri Rahayu Anargya: Jurnal Pendidikan Matematika, Vol. 1 No.1, April 2018

Laugsch, R.C. 2000. Scientific Literacy: A Conceptual Overview. Science Education, 84 (10): 71-94. 